\title{
Effects of flavonoid-induced oxidative stress on anti-H5N1 influenza a virus activity exerted by baicalein and biochanin $\mathrm{A}$
}

\author{
Martin Michaelis ${ }^{1,2+}$, Patchima Sithisarn ${ }^{1,3+}$ and Jindrich Cinatl Jr ${ }^{1 *}$
}

\begin{abstract}
Background: Different flavonoids are known to interfere with influenza A virus replication. Recently, we showed that the structurally similar flavonoids baicalein and biochanin A inhibit highly pathogenic avian H5N1 influenza A virus replication by different mechanisms in A549 lung cells. Here, we investigated the effects of both compounds on $\mathrm{H} 5 \mathrm{~N} 1$-induced reactive oxygen species (ROS) formation and the role of ROS formation during H5N1 replication.

Findings: Baicalein and biochanin A enhanced H5N1-induced ROS formation in A549 cells and primary human monocyte-derived macrophages. Suppression of ROS formation induced by baicalein and biochanin A using the antioxidant $\mathrm{N}$-acetyl-L-cysteine strongly increased the anti-H5N1 activity of both compounds in A549 cells but not in macrophages.

Conclusions: These findings emphasise that flavonoids induce complex pharmacological actions some of which may interfere with $\mathrm{H} 5 \mathrm{~N} 1$ replication while others may support $\mathrm{H} 5 \mathrm{~N} 1$ replication. A more detailed understanding of these actions and the underlying structure-activity relationships is needed to design agents with optimised anti-H5N1 activity.
\end{abstract}

Keywords: H5N1, Biochanin A, Baicalein, Antiviral, Reactive oxygen species, N-acetyl-L-cysteine

\section{Findings}

Highly pathogenic influenza A viruses including H5N1 viruses represent a major pandemic threat. Complication rates are much higher in $\mathrm{H} 5 \mathrm{~N} 1$ patients than in seasonal influenza or pandemic H1N1/09 patients [1-4]. As of $24^{\text {th }}$ January 2014, 650 confirmed human H5N1 cases had resulted in 386 deaths (www.who.int).

During an initial pandemic phase, matched vaccines will be restricted and antiviral drugs will be critical. The efficacy of the approved anti-influenza drugs (adamantanes, neuraminidase inhibitors) is limited, resistant strains emerge, and H5N1 strains appear to be less sensitive to the established anti-influenza drugs than seasonal influenza strains [1,4-13]. Hence, additional anti-influenza therapies are needed.

In 2009, the "WHO public health research agenda for Influenza" expressed a need for additional drugs including

\footnotetext{
* Correspondence: cinatl@em.uni-frankfurt.de

†Equal contributors

${ }^{1}$ Institute for Medical Virology, Clinics of the Goethe-University, Paul Ehrlich-Str. 40, 60596 Frankfurt am Main, Germany

Full list of author information is available at the end of the article
}

those that exert immunomodulatory effects and recommended to investigate natural products for anti-influenza activity (www.who.int). Flavonoids are known to exert multiple pharmacological effects including anti-inflammatory and anti-viral activities including inhibition of seasonal influenza A (H1N1) viruses [14-19]. They may interfere with the influenza virus neuraminidase [19-21], the virus host cell uptake [20,22], or cellular signalling events like the activation of nuclear factor kB (NFkB), AKT, ERK 1/2, p38, and/or JNK [23-27]. We showed recently that the flavonoids biochanin $\mathrm{A}$ and baicalein interfere with $\mathrm{H} 5 \mathrm{~N} 1$ replication in lung epithelial cells but that only baicalein inhibited H5N1 replication in primary human monocytederived macrophages [28]. Although biochanin A and baicalein are closely related structures (Figure 1A), they differed in their antiviral mechanisms. Inhibition of the H5N1 neuraminidase appeared to substantially contribute to the anti-H5N1 effects exerted by baicalein but not by biochanin A. Biochanin A interfered in contrast to baicalein with H5N1-induced activation of constituents of cellular signalling pathways [28] that are known to be 
A<smiles>COc1ccc(-c2coc3cc(O)cc(O)c3c2=O)cc1</smiles>

B
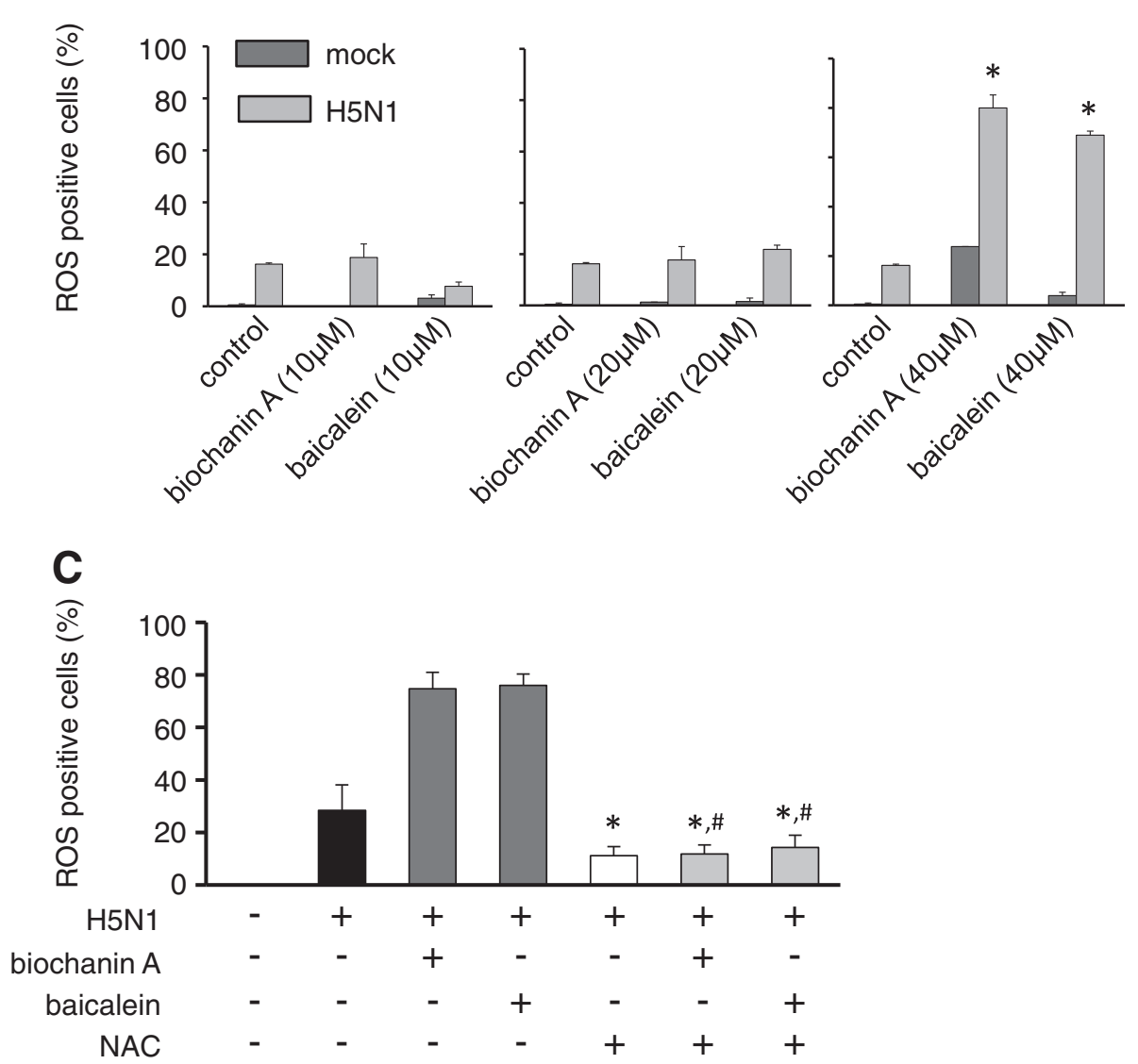

Figure 1 Effects of baicalein and biochanin on reactive oxygen species (ROS) formation in A549 cells infected with H5N1 strain A/Thailand/1(Kan-1)/04. A549 cells were treated continuously with the investigated flavonoids and/ or N-acetyl-L-cysteine (NAC) starting with a $1 \mathrm{~h}$ pre-incubation period prior to infection with H5N1 strain A/Thailand/1(Kan-1)/04 (MOI 0.01). ROS formation was detected at 24 h post infection. A) Chemical structures of biochanin A and baicalein; B) Effects of different baicalein or biochanin A concentrations on H5N1-induced ROS formation. ${ }^{*} \mathrm{P}<0.05$ relative to virus control; C) Effects of $\mathrm{N}$-acetyl-L-cysteine (NAC) $5 \mathrm{mM}$ on baicalein $40 \mu \mathrm{M}$ - or biochanin $\mathrm{A} 40 \mu \mathrm{M}$-induced ROS formation in $\mathrm{H} 5 \mathrm{~N} 1$-infected $\mathrm{A} 549$ cells. ' - ' indicates absence of virus or respective compound, ' + ' indicates presence of virus or respective compound. ${ }^{*} \mathrm{P}<0.05$ relative to virus control, ${ }^{\#} \mathrm{P}<0.05$ relative to respective flavonoid alone. Values are presented as mean \pm S.D. from three different independent experiments.

involved in influenza virus replication such as AKT, ERK $1 / 2$, and NFKB [10,29-32]. Notably, the effects of baicalein and biochanin $\mathrm{A}$ on $\mathrm{H} 5 \mathrm{~N} 1$ replication are complex and additional antiviral mechanisms are likely to contribute to their anti-H5N1 activities.

Flavonoids are known to differ in their effects on the formation of reactive oxygen species (ROS). They may display anti- or pro-oxidative effects [33]. Influenza virus replication is influenced by the cellular redox status [34]. The inhibition of virus-induced ROS formation by different strategies including the use of the antioxidant N-acetyl-Lcysteine (NAC) was shown to inhibit influenza A virus replication including $\mathrm{H} 5 \mathrm{~N} 1$ strains [34-36]. Here, we investigated the effects of baicalein and biochanin $\mathrm{A}$ on H5N1-induced ROS formation and the combined effects of baicalein and biochanin $\mathrm{A}$ in combination with the antioxidant $\mathrm{NAC}$ on $\mathrm{H} 5 \mathrm{~N} 1$ replication.

A549 cells (human lung carcinoma; ATCC, Manassass, VA, USA: CCL-185) and Vero cells (African green monkey kidney; ATCC: CCL81) were cultivated as described 
previously [28]. Human monocytes were isolated from buffy coats of healthy donors (Institute of Transfusion Medicine and Immune Haematology, German Red Cross Blood Donor Centre, Goethe-University, Frankfurt/Main, Germany) and $\mathrm{CD} 14^{+}$monocytes were differentiated into MDMs as described previously [28]. Cells were infected with H5N1 strain A/Thailand/1(Kan-1)/04 (obtained from Dr. Puthavathana, Mahidol University, Bangkok, Thailand) and virus titres were determined as $50 \%$ tissue culture infectious dose $\left(\mathrm{TCID}_{50} / \mathrm{mL}\right)$ as described previously [28]. Flavonoids, NAC, or their combinations were present starting from a $1 \mathrm{~h}$ pre-incubation period prior to infection. For the identification of statistically significant differences $(\mathrm{P}<0.05)$, two groups were compared by Student's $t$-test, more groups by ANOVA followed by subsequent stepwise multiple comparison procedure using the StudentNewman-Keuls method.

H5N1 infection of A549 cells at a multiplicity of infection (MOI) 0.01 resulted in enhanced ROS formation compared to control $24 \mathrm{~h}$ after infection (Figure 1B) as indicated by the use of the Image-iT LIVE Green Reactive Oxygen Species Kit (Molecular Probes, distributed by Invitrogen, Karlsruhe, Germany). Baicalein and biochanin A (both obtained from Indofine Chemical Company, Hillsborough, NJ, USA) did not influence ROS levels in non-infected or H5N1-infected cells in concentrations up to $20 \mu \mathrm{M}$. However, at a concentration of $40 \mu \mathrm{M}$ both compounds increased the ROS levels in non-infected as well as H5N1-infected cells (Figure 1B) despite the differences in their modes of anti-H5N1 action [28]. An NAC (obtained from Alexis, distributed by Axxora, Germany, dissolved in unsupplemented MEM and adjusted to $\mathrm{pH} 7.4$ with $\mathrm{NaOH}$ ) concentration of $5 \mathrm{mM}$ was sufficient to reduce the ROS levels below the levels observed in non-treated H5N1-infected A549 cells (Figure 1C).

Next, we investigated whether the reduction of baicalein- or biochanin A-induced enhanced ROS levels in H5N1-infected A549 cells by NAC influences the antiviral effects of these flavonoids. H5N1 (MOI 0.01)-infected A549 cells were treated with baicalein $40 \mu \mathrm{M}$ or biochanin A $40 \mu \mathrm{M}$ in combination with NAC in concentrations ranging from 1.25 to $5 \mathrm{mM}$. NAC did not affect cell viability alone or in combination with baicalein or biochanin $\mathrm{A}$ in the investigated concentrations as indicated by the CellTiter-Glo ${ }^{\oplus}$ Luminescent Cell Viability Assay (Promega GmbH, Mannheim, Germany) (data not shown). While NAC $5 \mathrm{mM}$ alone moderately reduced H5N1 titres (2.2fold reduction), NAC $2.5 \mathrm{mM}$ or $1.25 \mathrm{mM}$ did not significantly affect virus titres (Figure 2A). However, NAC reduced $\mathrm{H} 5 \mathrm{~N} 1$ titres in combination with baicalein or biochanin $\mathrm{A}$ in a dose-dependent manner in this concentration range in A549 cells (Figure 2B). Notably, NAC also inhibited baicalein- and biochanin A-induced oxidative stress in H5N1-infected primary human monocyte-

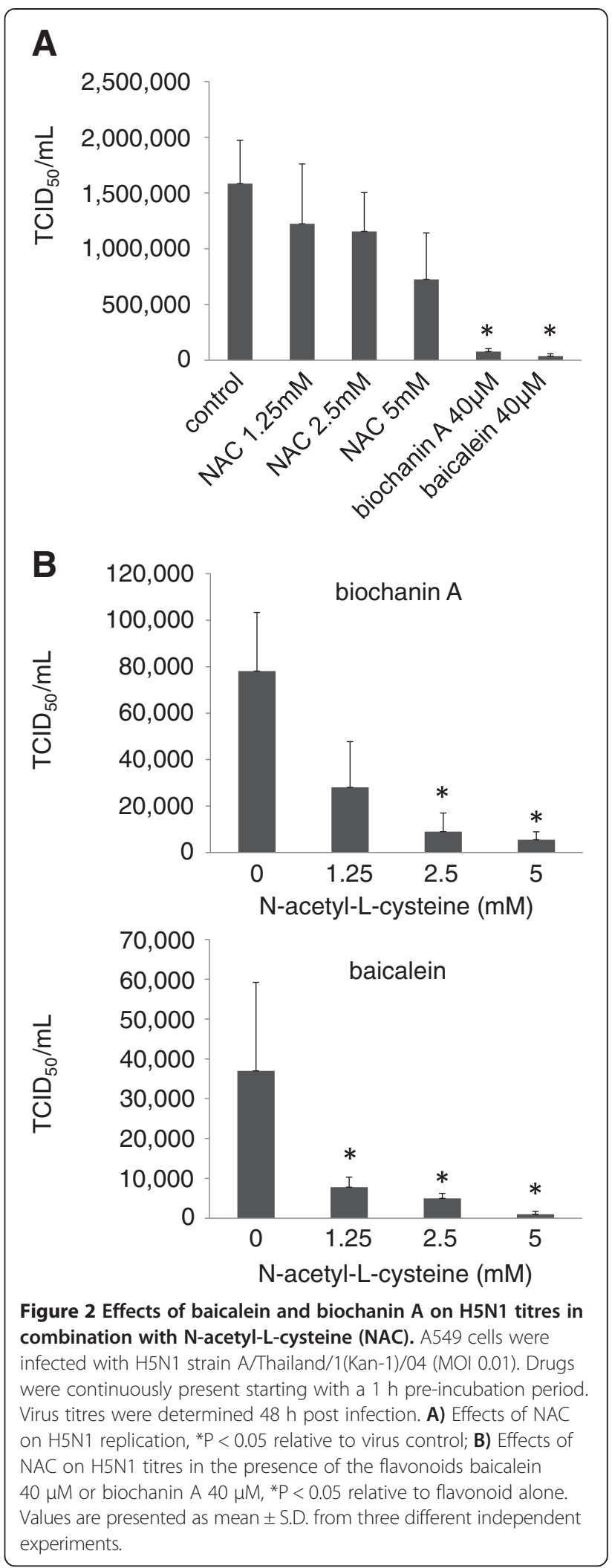


derived macrophages but did not affect $\mathrm{H} 5 \mathrm{~N} 1$ replication in this cell type (Figure 3). Human monocytes had been isolated from buffy coats of healthy donors, obtained from the Institute of Transfusion Medicine and Immune Haematology, German Red Cross Blood Donor Center, Johann Wolfgang Goethe-University, Frankfurt am Main.

In conclusion, we show that two flavonoids that interfere with $\mathrm{H} 5 \mathrm{~N} 1$ replication by different mechanisms of action exert similar effects at the level of ROS induction. Baicalein interferes with the H5N1 neuraminidase activity but biochanin does not. Biochanin A (but not baicalein) inhibits the activation of signalling molecules involved in H5N1induced signalling including AKT, ERK 1/2, and NFKB [28]. Despite these differences in their anti-H5N1 mechanisms, both compounds enhanced H5N1-induced ROS formation in A549 cells, and the efficacy of both compounds was enhanced by the antioxidant NAC. In contrast, inhibition of flavonoid-induced ROS formation by NAC did not affect virus replication in H5N1-infected macrophages. These findings emphasise that flavonoids, a class of natural compounds known to exert anti-influenza effects [16-19,28], induce a complex range of pharmacological actions by which they modify influenza A virus replication including highly pathogenic avian H5N1 strains. These actions may be cell type-specific and include pro- and antiviral effects. The overall activity may be the result of the totality of effects exerted by a certain flavonoid in a certain cell type. A more detailed understanding of these actions and the underlying structure-activity relationships is needed in order to design structures with optimised anti-influenza activity.

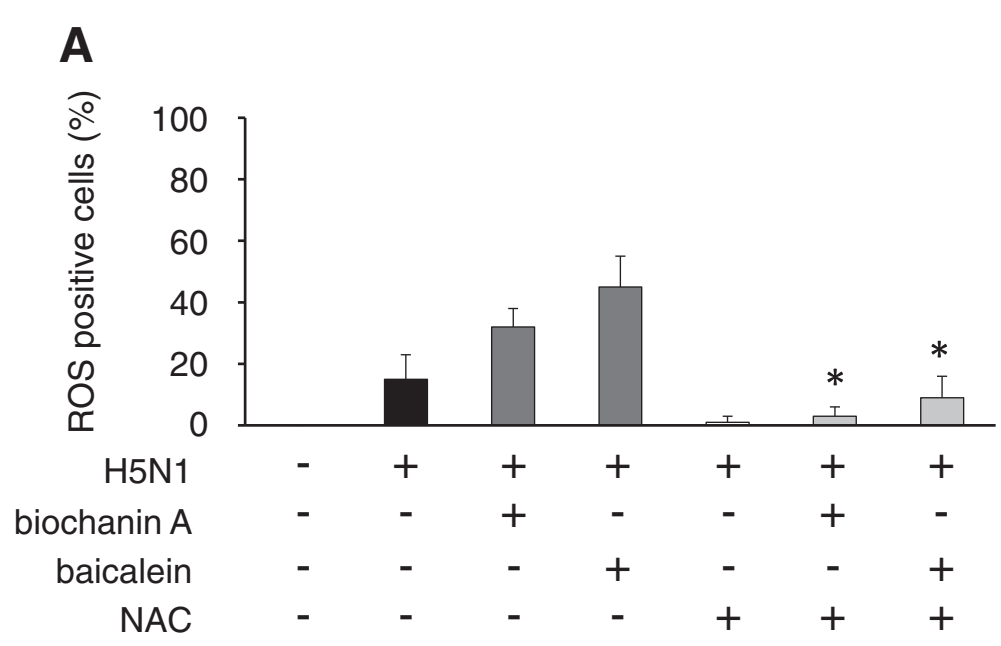

B

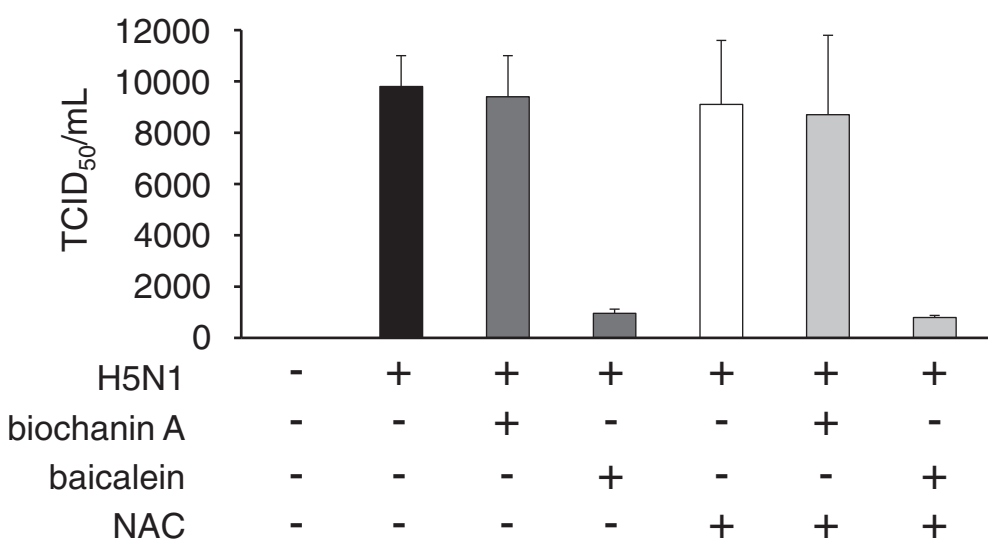

Figure 3 Effects of baicalein and biochanin A on reactive oxygen species (ROS) formation and H5N1 replication in primary human monocyte-derived macrophages in combination with $\mathrm{N}$-acetyl-L-cysteine (NAC). Macrophages were infected with H5N1 strain A/Thailand/1 (Kan-1)/04 (MOI 1). Drugs were continuously present starting with a $1 \mathrm{~h}$ pre-incubation period. Virus titres were determined $48 \mathrm{~h}$ post infection. A) Effects of flavonoids $40 \mu \mathrm{M}$ and/or NAC $5 \mathrm{mM}$ on H5N1-induced ROS formation, '-' indicates absence of virus or respective compound, '+' indicates presence of virus or respective compound. ${ }^{*} \mathrm{P}<0.05$ relative to flavonoids alone; B) Effects of baicalein $40 \mu \mathrm{M}$ or biochanin A $40 \mu \mathrm{M}$ in the presence or absence of NAC 5 mM on H5N1 titres. ' - ' indicates absence of virus or respective compound, ' + ' indicates presence of virus or respective compound. Values are presented as mean \pm S.D. from three different independent experiments. 


\section{Abbreviations}

NAC: N-acetyl-L-cysteine; ROS: Reactive oxygen species.

\section{Competing interests}

The authors declare that they have no competing interests.

\section{Authors' contributions}

MM and JC designed the study, analysed the data, and wrote the manuscript. PS performed experiments and analysed data. All authors read and approved the final manuscript.

\section{Acknowledgements}

The authors thank Mrs. Christina Matreux, Mrs. Kerstin Euler, Mrs. Gesa Meincke, and Mrs. Rosy Schmidt for technical supports. This work was supported by the EU (SARS/FLU vaccine/ proposal no. 512054, Chimeric Vaccines/ proposal no. 512864, Intranasal H5 vaccine, proposal no. 044512), by the Hilfe für krebskranke Kinder Frankfurt e.V., and by the Frankfurter Stiftung für krebskranke Kinder. P. Sithisarn was supported by a FRA scholarship from the Royal Thai Government.

\section{Author details}

Institute for Medical Virology, Clinics of the Goethe-University, Paul Ehrlich-Str. 40, 60596 Frankfurt am Main, Germany. ${ }^{2}$ Current address: Centre for Molecular Processing and School of Biosciences, University of Kent, Canterbury CT2 7NJ, UK. ${ }^{3}$ Current address: Faculty of Veterinary Medicine, Kasetsart University, Bangkok 10900, Thailand

Received: 24 April 2014 Accepted: 13 June 2014

Published: 23 June 2014

\section{References}

1. Cheung CL, Rayner JM, Smith GJ, Wang P, Naipospos TS, Zhang J, Yuen KY, Webster RG, Peiris JS, Guan Y, Chen H: Distribution of amantadine-resistant $\mathrm{H} 5 \mathrm{~N} 1$ avian influenza variants in Asia. $J$ Infect Dis 2006, 193:1626-1629.

2. de Jong MD: H5N1 transmission and disease: observations from the frontlines. Pediatr Infect Dis J 2008, 27:S54-S56.

3. Hien ND, Ha NH, Van NT, Ha NT, Lien TT, Thai NQ, Trang VD, Shimbo T, Takahashi Y, Kato Y, Kawana A, Akita S, Kudo K: Human infection with highly pathogenic avian influenza virus (H5N1) in northern Vietnam, 2004-2005. Emerg Infect Dis 2009, 15:19-23.

4. McKimm-Breschkin JL, Selleck PW, Usman TB, Johnson MA: Reduced sensitivity of influenza A (H5N1) to oseltamivir. Emerg Infect Dis 2007, 13:1354-1357.

5. Deyde VM, Xu X, Bright RA, Shaw M, Smith CB, Zhang Y, Shu Y, Gubareva LV, Cox NJ, Klimov Al: Surveillance of resistance to adamantanes among influenza $\mathrm{A}(\mathrm{H} 3 \mathrm{~N} 2)$ and $\mathrm{A}(\mathrm{H} 1 \mathrm{~N} 1)$ viruses isolated worldwide. J Infect Dis 2007, 196:249-257.

6. Hampson AW: Vaccines for pandemic influenza. The history of our current vaccines, their limitations and the requirements to deal with a pandemic threat. Ann Acad Med Singapore 2008, 37:510-517.

7. Kieny MP, Fukuda K: The pandemic influenza vaccine challenge. Vaccine 2008, 26(Suppl 4):D3-D4.

8. Sugrue RJ, Tan BH, Yeo DS, Sutejo R: Antiviral drugs for the control of pandemic influenza virus. Ann Acad Med Singapore 2008, 37:518-524.

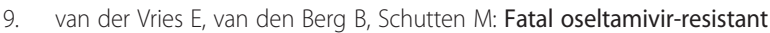
influenza virus infection. N Engl J Med 2008, 359:1074-1076.

10. Michaelis M, Doerr HW, Cinatl J Jr: Of chickens and men: avian influenza in humans. Curr Mol Med 2009, 9:131-151.

11. Moscona A: Global transmission of oseltamivir-resistant influenza. N Engl J Med 2009, 360:953-956.

12. Bavagnoli L, Maga G: The 2009 influenza pandemic: promising lessons for antiviral therapy for future outbreaks. Curr Med Chem 2011, 18:5466-5475.

13. Salter A, Ni LB, Crowley B: Emergence and phylogenetic analysis of amantadine-resistant influenza a subtype H3N2 viruses in Dublin, Ireland, over Six Seasons from 2003/2004 to 2008/2009. Intervirology 2011, 54:305-315.
14. Harborne JB, Williams CA: Advances in flavonoid research since 1992. Phytochemistry 2000, 55:481-504.

15. Nijveldt RJ, van Nood E, van Hoorn DE, Boelens PG, van Norren K, van Leeuwen PA: Flavonoids: a review of probable mechanisms of action and potential applications. Am J Clin Nutr 2001, 74:418-425.

16. Kim Y, Narayanan S, Chang KO: Inhibition of influenza virus replication by plant-derived isoquercetin. Antiviral Res 2010, 88:227-235.

17. Xu G, Dou J, Zhang L, Guo Q, Zhou C: Inhibitory effects of baicalein on the influenza virus in vivo is determined by baicalin in the serum. Biol Pharm Bull 2010, 33:238-243.

18. Chen L, Dou J, Su Z, Zhou H, Wang H, Zhou W, Guo Q, Zhou C: Synergistic activity of baicalein with ribavirin against influenza $A$ (H1N1) virus infections in cell culture and in mice. Antiviral Res 2011, 91:314-320.

19. Grienke U, Schmidtke M, von Grafenstein S, Kirchmair J, Liedl KR, Rollinger JM: Influenza neuraminidase: a druggable target for natural products. Nat Prod Rep 2012, 29:11-36.

20. Wang $X$, Jia W, Zhao A, Wang X: Anti-influenza agents from plants and traditional Chinese medicine. Phytother Res 2006, 20:335-341.

21. Liu AL, Wang HD, Lee SM, Wang YT, Du GH: Structure-activity relationship of flavonoids as influenza virus neuraminidase inhibitors and their in vitro anti-viral activities. Bioorg Med Chem 2008, 16:7141-7147.

22. Song JM, Park KD, Lee KH, Byun YH, Park JH, Kim SH, Kim JH, Seong BL: Biological evaluation of anti-influenza viral activity of semi-synthetic catechin derivatives. Antiviral Res 2007, 76:178-185.

23. Biswas SK, McClure D, Jimenez LA, Megson IL, Rahman I: Curcumin induces glutathione biosynthesis and inhibits NF-kappaB activation and interleukin-8 release in alveolar epithelial cells: mechanism of free radical scavenging activity. Antioxid Redox Signal 2005, 7:32-41

24. Hecht SS, Huang C, Stoner GD, Li J, Kenney PM, Sturla SJ, Carmella SG Identification of cyanidin glycosides as constituents of freeze-dried black raspberries which inhibit anti-benzo[a]pyrene-7,8-diol-9, 10-epoxide induced NFkappaB and AP-1 activity. Carcinogenesis 2006, 27:1617-1626.

25. Sen P, Chakraborty PK, Raha S: Tea polyphenol epigallocatechin 3-gallate impedes the anti-apoptotic effects of low-grade repetitive stress through inhibition of Akt and NFkappaB survival pathways. FEBS Lett 2006, 580:278-284

26. Cavet ME, Harrington KL, Vollmer TR, Ward KW, Zhang JZ: Antiinflammatory and anti-oxidative effects of the green tea polyphenol epigallocatechin gallate in human corneal epithelial cells. Mol Vis 2011, 17:533-542.

27. Kole L, Giri B, Manna SK, Pal B, Ghosh S: Biochanin-A, an isoflavon, showed anti-proliferative and anti-inflammatory activities through the inhibition of iNOS expression, p38-MAPK and ATF-2 phosphorylation and blocking NFkappaB nuclear translocation. Eur J Pharmacol 2011, 653:8-15.

28. Sithisarn P, Michaelis M, Schubert-Zsilavecz M, Cinatl J Jr: Differential antiviral and anti-inflammatory mechanisms of the flavonoids biochanin $\mathrm{A}$ and baicalein in $\mathrm{H} 5 \mathrm{~N} 1$ influenza A virus-infected cells. Antiviral Res 2013, 97:41-48

29. Shin YK, Liu Q, Tikoo SK, Babiuk LA, Zhou Y: Effect of the phosphatidylinositol 3-kinase/Akt pathway on influenza A virus propagation. J Gen Virol 2007, 88:942-950

30. Geiler J, Michaelis M, Sithisarn P, Cinatl J Jr: Comparison of proinflammatory cytokine expression and cellular signal transduction in human macrophages infected with different influenza A viruses. Med Microbiol Immunol 2011, 200:53-60.

31. Ludwig S: Disruption of virus-host cell interactions and cell signaling pathways as an anti-viral approach against influenza virus infections. Biol Chem 2011, 392:837-847

32. Pinto R, Herold S, Cakarova L, Hoegner K, Lohmeyer J, Planz O, Pleschka S: Inhibition of influenza virus-induced NF-kappaB and Raf/MEK/ERK activation can reduce both virus titers and cytokine expression simultaneously in vitro and in vivo. Antiviral Res 2011, 92:45-56. 
33. Khan HY, Zubair H, Ullah MF, Ahmad A, Hadi SM: A prooxidant mechanism for the anticancer and chemopreventive properties of plant polyphenols. Curr Drug Targets 2012, 13:1738-1749.

34. Vlahos R, Stambas J, Selemidis S: Suppressing production of reactive oxygen species (ROS) for influenza A virus therapy. Trends Pharmacol Sci 2012, 33:3-8.

35. Geiler J, Michaelis M, Naczk P, Leutz A, Langer K, Doerr HW, Cinatl J Jr: $\mathrm{N}$-acetyl-L-cysteine (NAC) inhibits virus replication and expression of pro-inflammatory molecules in A549 cells infected with highly pathogenic H5N1 influenza A virus. Biochem Pharmacol 2010, 79:413-420.

36. Michaelis M, Geiler J, Naczk P, Sithisarn P, Leutz A, Doerr HW,

Cinatl I Jr: Glycyrrhizin exerts antioxidative effects in H5N1 influenza A virus-infected cells and inhibits virus replication and pro-inflammatory gene expression. PLoS One 2011, 6:e19705.

doi:10.1186/1756-0500-7-384

Cite this article as: Michaelis et al:: Effects of flavonoid-induced oxidative stress on anti-H5N1 influenza a virus activity exerted by baicalein and biochanin A. BMC Research Notes 2014 7:384.

\section{Submit your next manuscript to BioMed Central and take full advantage of:}

- Convenient online submission

- Thorough peer review

- No space constraints or color figure charges

- Immediate publication on acceptance

- Inclusion in PubMed, CAS, Scopus and Google Scholar

- Research which is freely available for redistribution 